\title{
Agromorphological performance of garlic landraces in Piauí, Brazil
}

\author{
José de Ribamar de Araújo Albuquerque ${ }^{1}$ Hélio Nelson Brito Monteiro ${ }^{2}$ \\ Antônio Aécio de Carvalho Bezerra ${ }^{3}$ Carlos Humberto Aires Matos Filho ${ }^{4}$ \\ Ângela Celis de Almeida Lopes ${ }^{4}$ Regina Lucia Ferreira Gomes ${ }^{4^{*}}$
}

\footnotetext{
${ }^{1}$ Programa de Pós-graduação em Agronomia, Centro de Ciências Agrárias (CCA), Universidade Federal do Piauí (UFPI), Teresina, PI, Brasil. ${ }^{2}$ Centro de Ciências Agrárias (CCA), Teresina, PI, Brasil.

${ }^{3}$ Departamento de Planejamento e Política Agrícola, Centro de Ciências Agrárias (CCA), Universidade Federal do Piauí (UFPI), Teresina, PI, Brasil. ${ }^{4}$ Departamento de Fitotecnia, Centro de Ciências Agrárias (CCA), Universidade Federal do Piauí (UFPI), 64049-550, Teresina, PI, Brasil. E-mail: rlfgomes@ufpi.edu.br. "Corresponding author.
}

\begin{abstract}
In garlic (Allium sativum L.), genotype evaluation facilitates the search for better varieties. The aim of this study was to use morphoagronomic traits to evaluate three garlic landraces, namely, "Cateto Roxo Local", "Cateto Roxo Mineiro 1 " and "Cateto Roxo Mineiro 2". They were planted on May 1, 2014 and May 23, 2014, in the municipality of Sussuapara, State of Piaui, Brazil. These varieties have similar behavior at the vegetative stage. "Cateto Roxo Local" had the highest average bulb mass, clove number per bulb, and clove mass per bulb. "Cateto Roxo Mineiro 1" and "Cateto Roxo Mineiro 2" had the largest clove diameter per bulb. In Sussuapara-PI, "Cateto Roxo Mineiro 1" and "Cateto Roxo Mineiro 2" are recommended for planting in the beginning of May, whereas "Cateto Roxo Local" should be planted in the third week of May.
\end{abstract}

Key words: Allium sativum, planting dates, semi-noble garlic.

Desempenho agromorfológico de variedades crioulas de alho no Piauí

RESUMO: Na cultura do alho (Allium sativum L.), a atividade de avaliação de genótipos é importante na busca por variedades superiores e adaptadas. Nesse sentido, o objetivo do presente trabalho foi realizar avaliação agromorfológica em três variedades crioulas de alho, Cateto Roxo Local, Cateto Roxo Mineiro 1 e Cateto Roxo Mineiro 2, em duas épocas de plantio, 1 de maio e 23 de maio de 2014 , no município de Sussuapara - Piauí. As variedades apresentam comportamento semelhante na fase vegetativa das plantas, considerando as duas épocas de plantio. Quanto aos caracteres relacionados à produção, Cateto Roxo Local apresentou maior média para massa de bulbos, número e massa de bulbilhos por bulbo, enquanto Cateto Roxo Mineiro 1 e Cateto Roxo Mineiro 2, se destacaram quanto ao diâmetro dos bulbilhos por bulbo. Cateto Roxo Mineiro 1 e 2 devem ser recomendadas para o plantio no início do mês de maio, enquanto para Cateto Roxo Local, o plantio pode ocorrer até a terceira semana de maio, em Sussuapara - PI.

Palavras-chave: Allium sativum, época de plantio, alho seminobre.

\section{INTRODUCTION}

In Brazil, garlic (Allium sativum L.) production first began in the South and extended to other regions such as Minas Gerais, Goiás, and Bahia. In Piauí, garlic production is localized in Sussuapara, Santo Antônio de Lisboa, and Bocaina (SANTOS et al., 2016).

Two garlic types are produced in Brazil. Common white garlic has small bulbs, many bulbils, and little commercial value. It is classified as seminoble garlic. Noble garlic has large bulbs, fewer bulbils, and high commercial value. Semi-noble garlic production was usually conducted by small family farmers who sold their product informally in small marketplaces. Semi-noble garlic production significantly declined due to the introduction of noble garlic, vernalization, and the importation of garlic from China and Argentina (FAO, 2014).

Several factors contributed to the decline in garlic production in the Picos micro-region of Piauí: low seed garlic quality, suboptimal soil usage, river pollution and silting, and inadequate crop management due to the lack of technical guidance. Other factors included loss of traditional farming practices and the product failing to meet market requirements (SANTOS et al., 2016).

In the quest for superior garlic varieties, the characterization and evaluation of accessions are necessary to increase knowledge about the collections stored in germplasm banks and to identify genotypes 
with desirable traits that can be used in garlic breeding programs (MOTA, 2005). The study of local semi-noble garlic varieties during predetermined planting seasons helps building a better selection of productive genetic material suited to regional soil and climate conditions.

Multivariate analysis techniques combine data from multiple variables for genotype characterization. Principal components analysis has been widely used in genetic diversity studies because it creates groups that simplify data, reduce the number of variables, and facilitate the interpretation of results (HONGYU et al., 2015).

The aim of this study was to perform an agromorphological evaluation of three semi-noble garlic landraces during two planting seasons in Sussuapara, Piauí, Brazil.

\section{MATERIALS AND METHODS}

The experiment was conducted in Sussuapara, Picos micro-region, Piauí, Brazil, from May to September 2014. During this period, rainfall was $99.30 \mathrm{~mm}$ and the average temperature was $28.4^{\circ} \mathrm{C}$. The main local vegetation consists of cerrado and caatinga. The local soil is classified as eutrophic equivalent red-yellow podzolic (EMBRAPA, 1986).

The experimental design consisted of randomized blocks with four replications using a $3 \times 2$ factorial scheme. Three semi-noble garlic landraces were evaluated (Cateto Roxo Local, Cateto Roxo Mineiro 1, and Cateto Roxo Mineiro 2). These varieties could be cultivated over two planting seasons (May 1, 2014, and May 23, 2014). The experimental plot consisted of four rows each $1 \mathrm{~m}$ long, with $0.10 \mathrm{~m}$ spacing between plants and $0.50 \mathrm{~m}$ spacing between rows. The usable area consisted of two central rows each with eight useful plants. The plants at the end of each row constituted the border.

The soil was prepared by plowing and harrowing followed by soil bed construction. The soil was fertilized according to its physicochemical analysis. The experimental area was treated with $40 \mathrm{~kg}$ potassium chloride $\mathrm{ha}^{-1}$ and $250 \mathrm{~kg}$ single superphosphate $\mathrm{ha}^{-1}$. Nitrogen fertilization was performed using $100 \mathrm{~kg}$ urea ha- ${ }^{-1}$. One-third of this amount was applied as a base dressing and for the remaining $30 \mathrm{~d}$ and $60 \mathrm{~d}$ after planting.

Bulbils fitting a No. 2 sieve $(1.5 \times 1.5 \mathrm{~cm}$ screen) were selected from the previous year and used to standardize the culture development. Cateto Roxo seed bulbs were obtained from Sussuapara, Piauí, Brazil, and the other varieties from Francisco de Sá, Minas Gerais, Brazil.

After planting, a pre-emergent herbicide recommended for the crop (oxadiazon) was applied at the label rate of $4 \mathrm{~L} \mathrm{ha}^{-1}$. Plots were manually cleaned regularly to prevent the proliferation of competitor weeds. The plots were irrigated using a sprinkler irrigation system at a 1d interval and at depths according to the evapotranspiration rate of the crop.

The following parameters were evaluated 90d after planting (DAP): plant height $(\mathrm{cm})$, leaf width $(\mathrm{cm})$, number of leaves, and pseudo-stem basal diameter $(\mathrm{cm})$. The crop was harvested when four senescent leaves appeared. This stage occurred 120DAP for Cateto Roxo Local and 150DAP for Cateto Roxo Mineiro. Plants were pre-cured by exposure to sunlight for $3 \mathrm{~d}$ after harvest. Leaves protected the bulbs from burning. The plants were subsequently stored in fine mesh net bags for $30 \mathrm{~d}$ in a ventilated area. After curing process, plants were "cleaned" by removing their shoots and roots so that the total bulb production per plot could be determined.

Five bulbs were randomly selected per plot and the following parameters were evaluated after the bulb-curing process: bulb diameter $(\mathrm{mm})$, number of bulbils per bulb, bulbil diameter (mm), bulb mass (g), bulbil mass (g), and total productivity (total bulb weight harvested in $\mathrm{g}$ per plot converted to $\mathrm{Mg} \mathrm{ha}^{-1}$ ).

The data was subjected to ANOVA and the means were compared using Tukey's test $(P<0.05)$. The relationships among phenotypic correlation coefficients were determined by principal components analysis (PCA) and interpreted using a biplot chart.

\section{RESULTS AND DISCUSSION}

The garlic landraces significantly differed $(P<0.05)$ in terms of plant height, leaf width, and pseudo-stem basal diameter. They had similar lengths and numbers of leaves. These parameters did not significantly differ among seasons or in the variety $x$ season interaction. The Cateto Roxo Local variety had a greater average height $(49.23 \mathrm{~cm})$ than the Cateto Roxo Mineiro $2(42.56 \mathrm{~cm})$ and the Cateto Roxo Mineiro $1(41.79 \mathrm{~cm})$ types. VELOSO et al. (1999) reported an average height of $48.55 \mathrm{~cm}$ for Cateto Roxo Local in the same micro-region. Cateto Roxo Mineiro 1 and Cateto Roxo Mineiro 2; however, grew to heights similar to those reported by OLIVEIRA et al. (2010) for the Mineira Hozan type $(43.2 \mathrm{~cm}) 90$ DAP in Diamantina, Minas Gerais, Brazil, whose soil and climate conditions are better suited for garlic production than those in the Picos micro-region. These results suggested that there is no significant difference in response to regional climate conditions among garlic varieties at this phenological stage. 
Leaf width was greater for Cateto Roxo Mineiro $1(1.52 \mathrm{~cm})$ and Cateto Roxo Mineiro 2 $(1.65 \mathrm{~cm})$ types than Cateto Roxo Local $(1.12 \mathrm{~cm})$. MOTA et al. (2005) studied the Gigante Curitibanos and Gigante Roxo semi-noble varieties and obtained leaf widths of $2.7 \mathrm{~cm}$ and $3.1 \mathrm{~cm}$, respectively.

The pseudo-stem basal diameter was larger for Cateto Roxo Mineiro $1(8.60 \mathrm{~cm})$ and Cateto Roxo Mineiro $2(9.04 \mathrm{~cm})$ than Cateto Roxo Local $(7.09 \mathrm{~cm})$. According to OLIVEIRA et al. (2010), the pseudo-stem base diameter starts to increase when it consumes its carbohydrate reserves and initiates bulbification. This process depends on the capacity of the plant to accumulate photoassimilates in the pseudo-stem and to translocate them posteriorly to the bulb. Varieties from Minas Gerais evidently have a higher capacity than other types to accumulate photoassimilates and translocate them to the bulb.

Bulb diameter significantly differed among seasons (Table 1). Larger bulb diameters were observed during the first season and so planting during the beginning of May favors bulbification since longer periods of mild nighttime temperatures occurred at this time. According to MOTA (2005), these results may have occurred due to variations in the climate conditions where the materials were cultivated. In the present study, the periods of mild nighttime temperature periods differed between the first and second planting seasons.

Number of bulbils per bulb significantly differed among landraces (Table 1). Cateto Roxo Local had more bulbils per bulb than Cateto Roxo
Mineiro 1 and Cateto Roxo Mineiro 2. Although these varieties are genotypically different from each other and are semi-noble garlic landraces, they were not expected to differ as much as they did in terms of bulbil numbers. HONORATO et al. (2013) obtained an average of twelve bulbils per bulb for the Branco Mossoró regional type in Mossoró, Rio Grande do Norte, Brazil. Although, the type is a regional clone, the authors stated that it presented with fewer bulbils than expected because the seed garlic was produced in a different region whose soil and climate conditions were more conducive to its development than those in Mossoró. A similar situation was observed for the Cateto Roxo Mineiro 1 and Cateto Roxo Mineiro 2 types from Francisco Sá, Minas Gerais, Brazil.

Bulbil diameters per bulb significantly differed only among types (Table 1). Cateto Roxo Mineiro 1 and Cateto Roxo Mineiro 2 had greater bulbil diameters than those of Cateto Roxo Local. Therefore, since the Minas Gerais varieties produce larger bulbils than others, they are better suited for the region of this study.

Significant differences were observed in terms of bulb and bulbil mass among types, seasons, and the interaction between types and seasons. Bulb mass did not significantly differ among varieties during the first planting season (Table 1). Nevertheless, in the second season, the bulb masses of Cateto Roxo Mineiro 1 and Cateto Roxo Mineiro 2 were 45.53\% and $49.40 \%$ lower, respectively, than that of Cateto Roxo Local. Bulb mass of Cateto Roxo Local was not

Table 1 - Parameters averages of bulb diameter (BD), number of bulbils per bulb (NBB), diameter of bulbils per bulb (DBB), and the outcome of the interactions between bulb mass (BM), bulbil mass per bulb (BMB) and bulb productivity $\left(\mathrm{Mg}^{-1}\right)$ evaluated for three cured garlic landraces during two planting seasons in Sussuapara, Piauí, Brazil, 2014.

\begin{tabular}{|c|c|c|c|c|c|c|}
\hline Landraces/Season $^{1}$ & \multicolumn{2}{|c|}{$\mathrm{BD}(\mathrm{mm})$} & \multicolumn{2}{|c|}{ NBB } & \multicolumn{2}{|c|}{$\mathrm{DBB}(\mathrm{mm})$} \\
\hline Cateto Roxo Local & \multicolumn{2}{|c|}{$36.92 \mathrm{a}$} & \multicolumn{2}{|c|}{$22.02 \mathrm{a}$} & \multicolumn{2}{|c|}{$9.05 \mathrm{~b}$} \\
\hline Cateto Roxo Mineiro 1 & \multicolumn{2}{|c|}{$35.36 \mathrm{a}$} & \multicolumn{2}{|c|}{$6.52 \mathrm{~b}$} & \multicolumn{2}{|c|}{$14.59 \mathrm{a}$} \\
\hline Cateto Roxo Mineiro 2 & \multicolumn{2}{|c|}{$35.15 \mathrm{a}$} & \multicolumn{2}{|c|}{$6.10 \mathrm{~b}$} & \multicolumn{2}{|c|}{$14.51 \mathrm{a}$} \\
\hline Season 1 & \multicolumn{2}{|c|}{$36.93 \mathrm{~A}$} & \multicolumn{2}{|c|}{$11.40 \mathrm{~A}$} & \multicolumn{2}{|c|}{$13.32 \mathrm{~A}$} \\
\hline Season 2 & \multicolumn{2}{|c|}{$34.69 \mathrm{~B}$} & & $0 \mathrm{~A}$ & \multicolumn{2}{|c|}{$12.11 \mathrm{~A}$} \\
\hline \multirow{2}{*}{ Landraces $^{2}$} & \multicolumn{2}{|c|}{-----------BM (g)---------- } & \multicolumn{2}{|c|}{------------BMB (g)---------- } & \multicolumn{2}{|c|}{----Productivity $\left(\mathrm{Mg} \mathrm{ha}^{-1}\right)----$} \\
\hline & Season 1 & Season 2 & Season 1 & Season 2 & Season 1 & Season 2 \\
\hline Cateto Roxo Local & $14.47 \mathrm{Aa}^{1}$ & $14.96 \mathrm{Aa}$ & $12.98 \mathrm{Aa}$ & $13.72 \mathrm{Aa}$ & $1.36 \mathrm{Aa}$ & $1.30 \mathrm{Aa}$ \\
\hline Cateto Roxo Mineiro 1 & $12.20 \mathrm{Aa}$ & $8.15 \mathrm{Bb}$ & $11.30 \mathrm{Aa}$ & $7.51 \mathrm{Ab}$ & $1.53 \mathrm{Aa}$ & $0.85 \mathrm{Bb}$ \\
\hline Cateto Roxo Mineiro 2 & $12.09 \mathrm{Aa}$ & $7.57 \mathrm{Bb}$ & $11.45 \mathrm{Aa}$ & $6.79 \mathrm{Bb}$ & $1.58 \mathrm{Aa}$ & $0.71 \mathrm{Bb}$ \\
\hline
\end{tabular}

${ }^{1}$ Averages for landrace with the same lowercase letter or for season with the same capital letter do not significantly differ according to Tukey's test $(P<0.05)$.

${ }^{2}$ Averages followed by the same capital letter in rows and same lowercase letter in columns do not significantly differ according to Tukey's test $(P<0.05)$. 
affected by the season factor. In the second season, the bulb masses of Cateto Roxo Mineiro 1 and 2 decreased by $33.20 \%$ and $37.40 \%$; respectively, relative to their bulb masses in the first season, and the differences were significant. These results indicated that the local type is adapted to the regional soil and climate conditions.

TREVISAN et al. (1997) evaluated the effect of planting season (March, April, and June) on the yield of noble, semi-noble, and regional garlic commercial bulbs in Santa Maria, Rio Grande do Sul, Brazil. They concluded that all types were affected by season. The authors reported that all varieties except the regional garlic type produced smaller bulbs in June season and that the greatest average weight reduction occurred in the short-cycle noble types. These results indicate that local types are less likely than others to be affected by planting seasons since they are adapted to the region.

Bulbils per bulb mass (Table 1) were similar among types during the first season. In the second season, Cateto Roxo Local had a higher bulbil mass than the Mineiros 1 and 2 types since it is better adapted to local climate conditions than the others. Bulbil masses of Mineiros 1 and 2 were $45.27 \%$ and $50.52 \%$ lower; respectively than that of Cateto Roxo Local. The average bulbil masses were similar for the Cateto Roxo Local and Cateto Roxo Mineiro 1 types. Cateto Roxo Mineiro 2 had a higher bulbil mass than the other two types during the first season (Table 1). Its bulbil mass decreased by $40.70 \%$ during the second season.

Bulb productivity (Table 1) differed significantly between seasons and the type $\mathrm{x}$ seasons interaction. During the first season, bulb productivity did not significantly differ among types. During the second season, the bulb productivities of Cateto Roxo Mineiro 1 and 2 were $34.62 \%$ and $45.40 \%$ lower, respectively than that of Cateto Roxo Local. Bulb productivities of the garlic types from Minas Gerais differed significantly among seasons. The highest averages were obtained during season 1 when bulbification was promoted by the long mild nighttime temperature periods. The bulb productivities of Cateto Roxo Mineiro 1 and 2 were $44.45 \%$ and $55.07 \%$ lower, respectively, than those of the first season.

Correlations among the nine quantitative parameters evaluated in this study were verified using phenotypical correlation coefficients because most of them were significant $(r>0.7)$. The pseudo-stem basal diameter was positively correlated with the leaf width (0.8936) and the bulbil diameter per bulb (0.9556). It was negatively correlated with the number of bulbils per bulb (-0.9603). Therefore, greater pseudo-stem development favors the production of bulbs with fewer large-diameter bulbils. This trait is desirable for garlic. Bulb production is correlated with the vegetative growth (ADEKPE et al., 2007). Garlic plants with well-developed vegetative structures have effective source-drain systems for nutrient and photoassimilate translocation to the bulbs from the leaves and the pseudo-stems. This property results in a greater potential for the production of large bulbs (MATHEW et al., 2011).

Principal components analysis (PCA) was conducted, because there were correlations between parameters. PCA showed that the first and second major components explained $91.47 \%$ and $8.43 \%$ of the data variation; respectively, and accounted for $99.90 \%$ of the variation observed. Therefore, the nine parameters studied may be replaced by these two components without any significant information loss. The magnitude of variation identified by the two principal components exceeded that reported by VIANA (2015). In their research with garlic types, they indicated that the first and second components explained 43.83\% and $22.33 \%$ of the total variation, respectively, and together they accounted for approximately $66.16 \%$ of it. MORRISON (1976) reported that, at least $75 \%$ of the total variation among accessions must be absorbed by the first two components.

A biplot chart (Figure 1) was used to analyze the responses of the garlic types to the quantitative parameters studied during the two planting seasons. Cateto Roxo Mineiro 1 and Cateto Roxo Mineiro 2 were grouped by production-related parameters (pseudo-stem basal diameter, bulb mass, bulb diameter, bulbil mass per bulb, bulbil diameter per bulb, and bulb productivity) during the first planting season. These types performed better during season 1 when mild nighttime temperature periods were longer and bulbification was favored. During the second planting season, Cateto Roxo Mineiro 1 and 2 had the lowest averages for production-related parameters (bulb mass, bulb diameter, bulbil mass per bulb, and bulb productivity). During seasons 1 and 2, the plant height and number of bulbils per bulb tended to increase for Cateto Roxo Local. Plant height had significant and strong positive correlations with the number of bulbils and a negative correlation with bulbil diameter per bulb. These are negative traits for garlic crops.

During the first planting season, Cateto Roxo Mineiro 1 and 2 had higher averages for production-related parameters. Therefore, they responded positively to the seasonal climate conditions. Conversely, the adapted Cateto Roxo Local responded in a similar way for both seasons. Thus, planting season did affect the genetic material. Cateto Roxo Mineiro 1 and 2 are recommended for planting at the beginning 


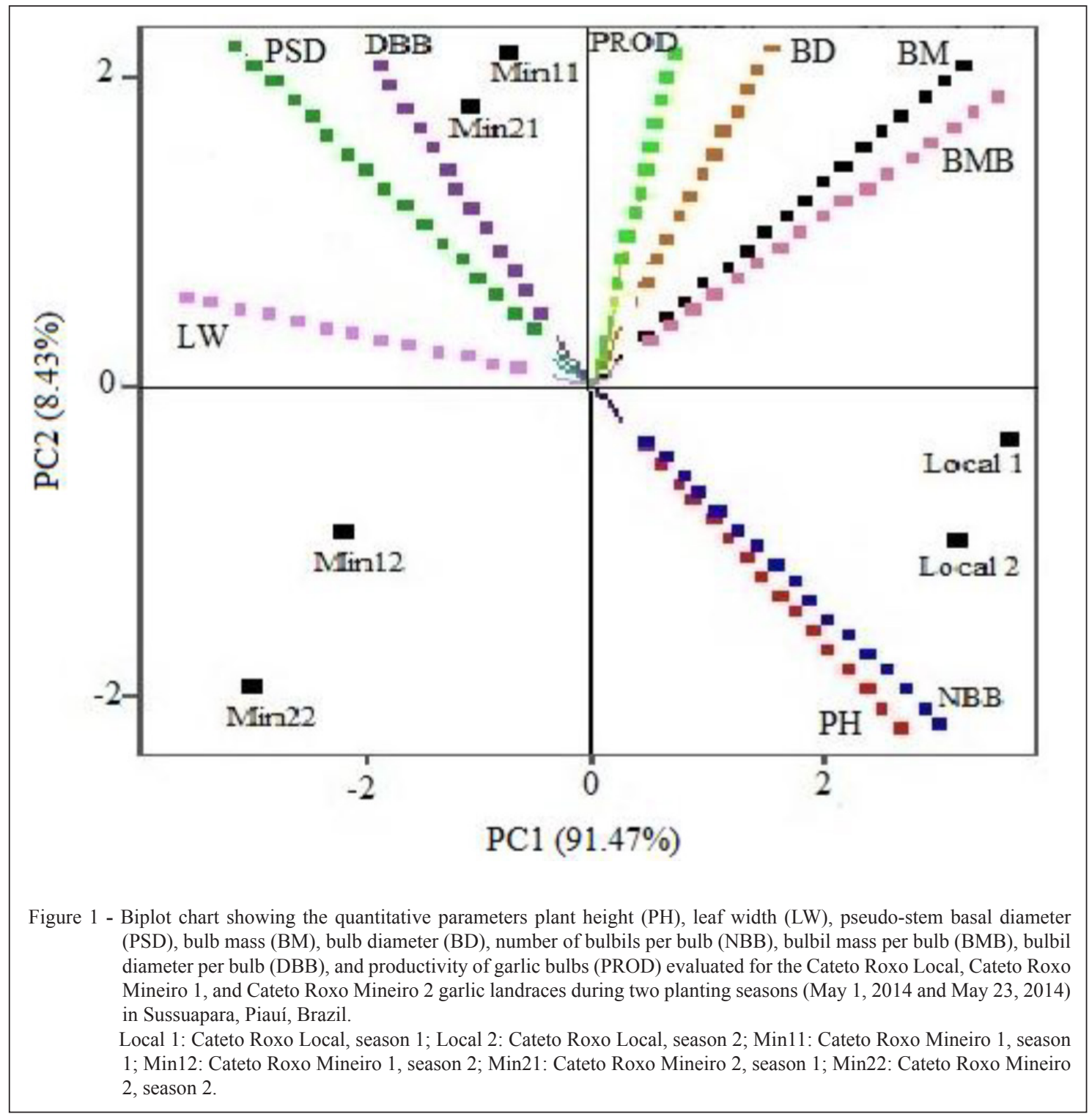

of May. In contrast, bulb productivity of Cateto Roxo Local will not be reduced even if planting is delayed.

\section{CONCLUSION}

The agromorphological performance of the Cateto Roxo Local garlic landrace performs best in terms of bulb mass and bulbil mass per bulb; whereas, Cateto Roxo Mineiro 1 and 2 are superior with respect to bulbil diameter per bulb.

In Sussuapara, Piauí, Brazil, Cateto Roxo Mineiro 1 and 2 garlic landraces are recommended for planting at the beginning of May whereas the adapted Cateto Roxo Local landrace can be planted until the third week of May.

\section{ACKNOWLEDGEMENTS}

To the Coordenação de Aperfeiçoamento de Pessoal de Nível Superior (CAPES) for granting the scholarship and to Conselho Nacional de Desenvolvimento Científico e Tecnológico (CNPq) for the research grant (\#484237/2010-1).

\section{REFERENCES}

ADEKPE, D.I. et al. Yield responses of garlic (Allium sativum L.) to oxidation, date of planting and intra-row spacing under irrigation at Kadawa, Nigeria. Crop Protection, Guildford, v.26, n.12, p.1785-1789, 2007. Available from: <http://ac.els-cdn.com/ S0261219407000816/1-s2.0-S0261219407000816-main.pdf? tid $=50 \mathrm{e} 7 \mathrm{a} 8 \mathrm{~d} 0-153 \mathrm{c}-11 \mathrm{e} 7-8674-00000 \mathrm{aacb} 35 \mathrm{e} \& \mathrm{acdnat}=1490873 \overline{6}$ 25_2b5d505b19426306d40feb8658700c0c>. Accessed: Nov. 21, 2015. doi: 10.1016/j.cropro.2007.03.019. 
EMBRAPA. Serviço Nacional de Levantamento e Conservação de Solo. Levantamento exploratório - reconhecimento de solos do Estado do Piaui. Rio de Janeiro: EMBRAPA-SNLCS. (Boletim de Pesquisa, 36; SUDENE-DNR. Série Recursos de Solos, 18), 1986. Available from: <http://www.uep.cnps. embrapa.br/solos/index.php?link=pi>. Accessed: Mar. 15, 2017.

HONGYU, K. et al. Principal component analysis: theory, interpretations and applications. Engineering and Science, Cuiabá, v.1, p.83-90, 2015. Available from: <http://periodicoscientificos.ufmt. br/ojs/index.php/eng/article/download/3398/2623>. Accessed: Mar. 15, 2017. doi: 10.18607/ES20165053.

HONORATO, A.R.F. et al. Avaliação de cultivares de alho na região de Mossoró. Revista Caatinga, Mossoró, v.26, n.3, p.80-88, 2013. Available from: <http://periodicos.ufersa.edu.br/index.php/ sistema>. Accessed: Nov. 21, 2015.

MATHEW, D. et al. Effect of long photoperiod on the reproductive and bulbing processes in garlic (Allium sativum L.) genotypes. Environmental and Experimental Botany, Elmsford, v.71, n.2, p.166-173, 2011. Available from: $<$ https://www.researchgate.net/publication/229183708 Effect_of_long_photoperiod_on_the_reproductive_and_bulbing processes_in_garlic_\%28A1lium_sativum_L.\%29_genotypes $>$. Accessed: Nov. 21, 2015. doi: 10.1016/j.envexpbot.2010.11.008.

MORRISON, D.F. Multivariate statistical methods. 5.ed. New York: McGraw-Hill, 1976. 85p.

MOTA, J.H. et al. Similaridade morfológica de cultivares de alho (Allium sativum L.). Revista Científica Eletrônica de
Agronomia, Garça, v.4, n.8, p.1-8, 2005. Available from: <https:// www.http://faef.revista.inf.br/imagens arquivos/arquivos destaque/7cLwUnEKVRLxrqy_2013-4-29-16-20-21.pdf>. Accessed: Nov. 21, 2015.

OLIVEIRA F.L. et al. Características agronômicas de cultivares de alho em Diamantina. Horticultura Brasileira, Brasília, v.28, n.3, p.355-359, 2010. Available from: <http:// dx.doi.org/10.1590/S0102-05362010000300019>. Accessed: Nov. 26, 2015.

SANTOS, K.B. et al. Repercussões da concorrência do alho (Allium sativum L.) importado no mercado local. Revista Espacios, Caracas, v.37, n.05, p.11-19, 2016. Available from: $<$ http://www.revistaespacios.com/a16v37n05/16370511.html $>$. Accessed: Nov. 22, 2015.

TREVISAN, J.N. et al. Influência da época de plantio na produção de classes de bulbos comerciais de cultivares de alho (Allium sativum L.) em Santa Maria, RS. Ciência Rural, Santa Maria, v.27, n.1, p.7-11, 1997. Available from: <http://dx.doi.org/10.1590/ S0103-84781997000100002>. Accessed: Nov. 26, 2015.

VELOSO, E.C. et al. Evaluation of garlic cultivars in Picos region, PI. Horticultura Brasileira, Brasília, v.17, n.3, p.234236, 1999. Available from: <http://dx.doi.org/10.1590/S010205361999000300012>. Accessed: Nov. 26, 2015.

VIANA, J.P.G. et al. Divergência genética em germoplasma de alho. Ciência Rural, Santa Maria, v.46, n.2, p.203-209, 2016. Available from: <http:// dx.doi.org/10.1590/0103-8478cr20130988>. Accessed: Dec. 17, 2015. 